Dept. of Food Hygiene,

Fac. of Vet. Med., South Valley University.

\title{
EVALUATION OF CHEMICAL AND MICROBIOLOGICAL QUALITY OF RAW GOAT MILK IN QENA PROVINCE
}

(With 3 Tables and One Figure)

\author{
By \\ KARIMA G. ABDEL-HAMEED
}

(Received at 15/3/2011)

\section{تقييم الجودة الكيميائية والميكروبيولوجية لحليب الماعز الخام في محافظة قنا}

\section{كريية جلال عبد الحملي}

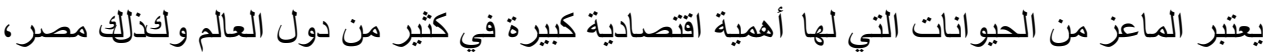

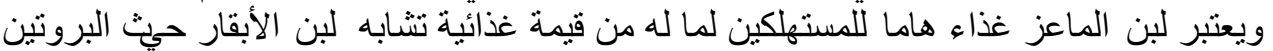

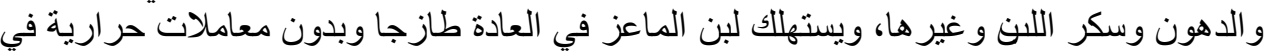

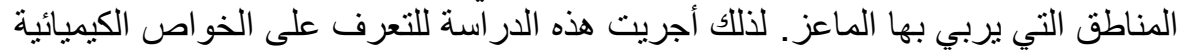
و الميكروبيولَوجية للبن الماعز الخام المتداول في محافظة قنا. وقد اشتملت الدر استة على فلى فحص

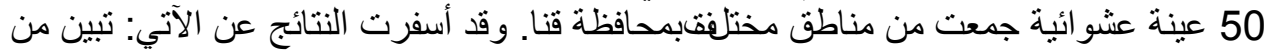

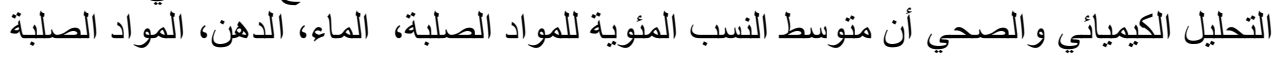

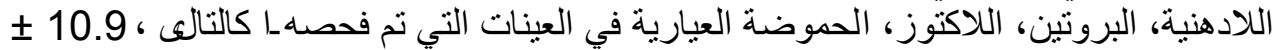

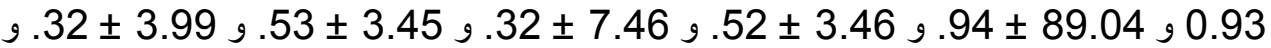

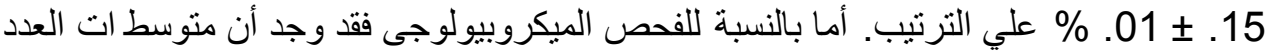

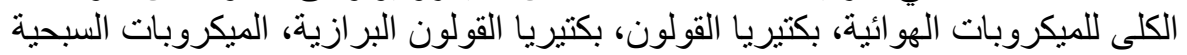

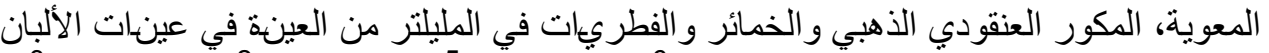

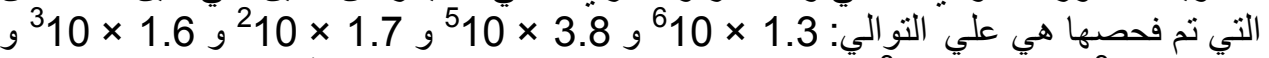

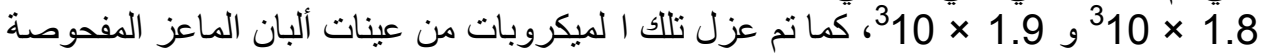

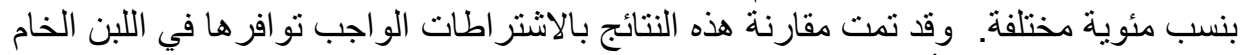

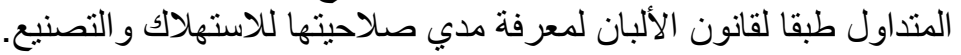

\section{SUMMARY}

Chemical and microbiological analyses were carried out on 50 random samples of raw goat's milk collected from different places in Qena province to evaluate their sanitary condition. The total solids of the examined goat's milk samples had a mean value of $10.9 \pm 0.93$ and ranged from $9.49 \%$ to $13.3 \%$, while, water contents ranged from $86.7 \%$ to $90.51 \%$ with a mean value of $89.04 \pm 0.94 \%$. Regarding fat $\%$ of the examined 
goat's milk samples, it was varied from $2.66 \%$ to $4.84 \%$ with a mean $\%$ of $3.46 \pm 0.52$. While, solids non fat $\%(\mathrm{SNF} \%)$ had a minimum of $6.57 \%$ and a maximum of $8.6 \%$ with a mean value of $7.46 \pm 0.32 \%$. Protein $\%$ was varied from $2.71 \%$ to $4.9 \%$ with a mean value of $3.45 \pm 0.53 \%$. The examined goat's milk samples had minimum lactose percentage of 2.73 and a maximum of 4.59 with a mean value of $3.99 \pm 0.32 \%$. The titratable acidity of the examined goat's milk samples as one of the keeping quality tests fluctuated between 0.09 and 0.26 with a mean value of $0.15 \pm 0.01 \%$. Concerning the microbiological results of the evaluated samples, it was found that the average counts for aerobic plate, coliforms, fecal coliforms, enterococci, $S$. aureus and yeasts \& molds were as follow $1.3 \times 10^{6}, 3.8 \times$ $10^{5}, 1.7 \times 10^{2}, 1.6 \times 10^{3}, 1.8 \times 10^{3}$ and $1.9 \times 10^{3}$ cells/ ml, respectively. The public health importance of the counted organisms and the prophylactic measures to improve the quality of dairy farm milk were discussed.

Key words: Chemical, Sanitary, Microbiological, Quality \& Raw goat's milk.

\section{INTRODUCTION}

Milk is a complex biological fluid which contains a wide variety of different constituents and possesses unique physical and chemical characteristics. The milk quality is determined by aspects of composition and hygiene. The hygienic parameters are decisive for food safety and might also influence the composition of milk. A test for assessing compositional quality has to be judged on three grounds: it must show nutritional value, be equitable and practical.

Protein, fat, vitamins and minerals are the constituents of milk which provide for nutritional needs, and the most valuable constituent is protein. Its importance is the supplemental value of associated vitamins especially riboflavin, and minerals, particularly calcium and phosphrous. Consequently, the solid non fat (SNF) of milk, especially the protein fraction, is the valuable constituents which nutritionally should determine the basis for any proposal for the production and use of milk and milk products. Likewise, milk fat function as a variable source of essential fatty acids, as well as, it may help to meet the food energy needs of a country has an inadequate caloric intake.

There is growing demand for unpasteurized goat's and ewe's milk by consumers (Harrington et al., 2002). This is due to the increasing number of children suffering from intolerance to cow's milk, as well as, to the demand for natural and unprocessed food (Park, 1994). Furthermore, protein energy malnutrition place a huge burden on health care facilities in 
developing countries and treatment should preferably based on food available locally and cow milk can't be produced at an affordable cost in many tropical countries. Goat's milk has a nutritional value similar to that of cow's milk and could be used as an alternative to cow's milk for rehabilitation of extremely mal-nourished children. Moreover, goats are more disease resistance than cows (Muehlherr et al., 2003). So, there is a clear need to find out more about the present situation regarding the quality of goat's milk.

Investigation on microbiological quality such as Total Plate Count (TPC), coliforms and the presence of pathogenic bacteria of goat's milk, together with some risk factors affecting these microorganisms in Qena province, was very rare. In fact, most of the goat milk is consumed in raw condition without any treatment. Therefore, in view of food hygiene and public health protection, however, evaluation of the microbiological status and presence of pathogenic bacteria in goat's milk, which can cause adverse health effects on the animals, as well as, pose a high risk of causing foodborne disease in humans, is of central importance. Therefore, this study was aimed to investigate the microbiological quality of raw goat milk by using indicator bacteria, and also to evaluate the potential risk factors associated with them.

Therefore, the objective of this study was to allow qualitative checking of hygienic conditions of examined raw goat's milk in Qena province chemically and microbiologically to check the suitability of such milk for public consumption, as well as, for processing of high quality dairy products.

\section{MATERIALS and METHODS}

\section{a) Samples collection:}

A total of 50 random samples of raw goat's milk were collected from different places in Qena province. The samples (in a sterile container) were transferred to the laboratory with a minimum of delay to be examined chemically, sanitary and microbiologically after thoroughly mixing.

\section{b) Chemical examinations:}

1- Detection of heat treatment by Storch's test (Lampert, 1975).

2- Determination of total solids percentage (A.O.A.C., 1990).

3- Determination of water percentage:

Water content was calculated by subtracting the total solids percentage from the original weight of the sample before drying.

4- Determination of fat percentage (A.P.H.A., 1985).

5- Determination of solids non fat percentage: 
The solids non fat percentage of the examined samples was calculated by subtracting the fat percentage from the total solids percentage.

6- Determination of protein percentage:

Using formal titration method as described by Schulz, et al. (1953) and modified by Mumm (1970).

7- Determination of lactose percentage (Harvey and Hill, 1967).

c) Sanitary examination:

1- Determination of titratable acidity percentage (A.O.A.C., 1990).

d) Microbiological examinations:

1- Aerobic plate count (A.P.H.A., 1985).

2- Determination of total Coliform and Fecal Coliform counts (Mercuri and Cox, 1979).

3- Enterococci count (Deibel and Hartman, 1976).

4- S. aureus count (A.O.A.C., 2000).

5- Yeast and Mold counts (Harrigan and McCance, 1976).

\section{RESULTS}

Table 1: Statistical analytical results of chemical composition of the examined goat's milk samples.

\begin{tabular}{|l|c|c|c|c|}
\hline Composition & No. of examined samples & Min. & Max. & Mean \pm SE \\
\hline T.S\% & 50 & 9.49 & 13.3 & $10.90 \pm 0.93$ \\
\hline Water \% & 50 & 86.7 & 90.51 & $89.04 \pm 0.94$ \\
\hline Fat \% & 50 & 2.66 & 4.84 & $3.46 \pm 0.52$ \\
\hline S.N.F \% & 50 & 6.57 & 8.6 & $7.46 \pm 0.32$ \\
\hline Protein \% & 50 & 2.71 & 4.9 & $3.45 \pm 0.53$ \\
\hline Lactose \% & 50 & 2.73 & 4.59 & $3.99 \pm 0.32$ \\
\hline
\end{tabular}

Table 2: Statistical analytical results of acidity $\%$ of the examined goat's milk samples.

\begin{tabular}{|c|c|c|c|}
\hline No. of examined samples & Min. & Max. & Mean \pm SE \\
\hline 50 & 0.09 & 0.26 & $0.15 \pm 0.01$ \\
\hline
\end{tabular}

Table 3: Statistical analytical results of microbiological examination of the examined goat's milk samples. 


\begin{tabular}{|l|c|c|c|c|l|}
\hline \multirow{2}{*}{$\begin{array}{c}\text { Microbiological } \\
\text { examinations }\end{array}$} & \multicolumn{2}{c|}{$\begin{array}{c}\text { Positive } \\
\text { samples }\end{array}$} & \multicolumn{3}{c|}{ Counts / ml } \\
\cline { 2 - 6 } & No./50 & $\%$ & Min. & Max. & Average \\
\hline Aerobic plate count & 50 & 100 & $2.2 \times 10^{3}$ & $8.7 \times 10^{8}$ & $1.3 \times 10^{6}$ \\
\hline Coliform count & 35 & 70 & $1.3 \times 10^{2}$ & $5.7 \times 10^{6}$ & $3.8 \times 10^{5}$ \\
\hline Fecal coliform count & 20 & 40 & $<10$ & $6.2 \times 10^{2}$ & $1.7 \times 10^{2}$ \\
\hline Enterococci count & 23 & 46 & $1.0 \times 10^{2}$ & $3.1 \times 10^{4}$ & $1.6 \times 10^{3}$ \\
\hline S. aureus count & 18 & 36 & $1.7 \times 10^{2}$ & $6.5 \times 10^{3}$ & $1.8 \times 10^{3}$ \\
\hline Yeast \& Mold counts & 46 & 92 & $1.0 \times 10$ & $2.3 \times 10^{4}$ & $1.9 \times 10^{3}$ \\
\hline
\end{tabular}

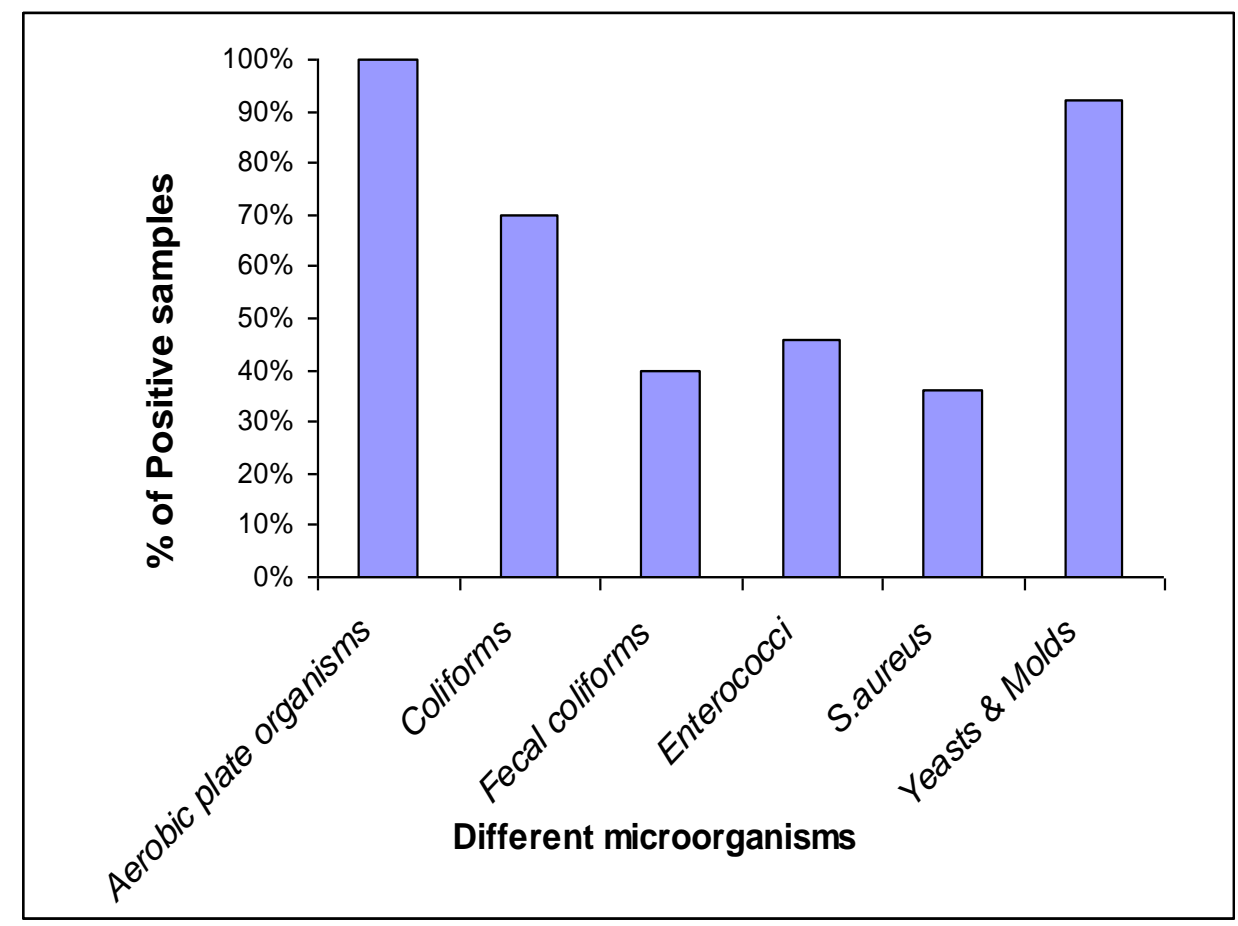

Fig. 1: Incidence of different microorganisms in the examined goat's milk samples.

\section{DISCUSSION}


Milk composition varies according to several factors, such as animal, feed and environment. Results given in Table 1 point out that T.S. content of the examined goat's milk samples ranged from 9.49 to $13.3 \%$ with a mean value of $10.9 \pm 0.93 \%$. These findings agree with those reported by Mahran (2000). Lower results obtained by Abou-Dawood et al. (1980) however, higher values were recorded by Psathas (2005); Albenzio et al. (2006) and Güler and Park (2009). The lower T.S. content could be attributed to partial skimming, added water or both partial skimming and addition of water.

Realizing the results presented in Table 1. it is evident that the water content of the examined goat's milk samples ranged from 86.7 to $90.51 \%$ with a mean value of $89.04 \pm 0.94 \%$. The obtained values were similar to the data estimated by Abou-Dawood, et al. (1980). Higher results were recorded by Mahran (2000), while, lower result was obtained by Zeng and Escobar (1996). The main function of water in milk is to hold the solids of the milk partly in the solution and partly in suspension. Adulteration by addition of water may lead to decrease the legal percentages of fat, total solids and solids non fat.

The data summarized in Table 1 verifies that the fat percentage of the examined goat's milk samples was varied from 2.66 to $4.84 \%$ with a mean value of $3.46 \pm 0.52 \%$. Similar fat contents of goat's milk were obtained by Güler and Park (2009). Higher values were recorded by Psathas (2005); Albenzio, et al. (2006) and Pirisi, et al. (2007); (3.6\%, $5.6 \%$ and $4.3 \%$, respectively). The variation in the results can be due to fat content is the more quantitatively and qualitatively variable component of milk, depending on lactation stage, season, breed, genotype and feeding of animals.

Nevertheless, the main characteristic of small ruminant milk fat, is the high content in short and medium chain fatty acids (MCFA), especially in goat's milk fat, which has at least twice as many C6-C10 fatty acids as cow's milk fat: 8, 12 and 16\% total fatty acid for cow's, ewe's and goat's milk fat, respectively (Chilliard et al., 2006; Paccard and Lagriffoul, 2006 a \& b). These fatty acids have a different metabolism from that of long chain fatty acids (Gurr, 1995 and Bach et al., 1996). MCFA could indeed be released from triglycerides in the stomach by gastric lipase and duodenum pancreatic lipase to be absorbed directly by intestinal cells, without esterification, and transported mainly via portal vein (depending on their chain length and initial position on triglycerides) to the liver, where they are rapidly oxidised. Thus, they constitute a rapid energetic supply, especially for those suffering from malnutrition or fat malabsorption syndrome. 
For instance, MCFA have been used since 1960 for pre-term newborns in specific ratio with long chain fatty acids (Telliez et al., 2002). They could also be used in a geriatric diet and may contribute to lower total circulating cholesterol. The rapid metabolism induces a postprandial thermal expenditure (Bendixen et al., 2002) and might be applied to human weight regulation, especially in overweight men (St Onge and Jones, 2002).

The other characteristic of small ruminant milk fat is their small globules size compared to cow milk. This property supports the hypothesis that goat's milk fat is more easily digested. Both fat globule size and the MCFA content of goat's milk are thought to have a beneficial effect on fat assimilation and energy supply in malnourished children (Razafindrakoto, et al., 1993).

Concerning the results given in Table 1, the solids non fat (SNF) percentage of the examined samples was $6.57 \%$ as a minimum and $8.6 \%$ as a maximum with a mean of $7.46 \pm 0.32$. These results approximately agree with those previously achieved by Zeng and Escobar (1996), while, higher finding was reported by Mahran (2000). The lower SNF content could be attributed mainly to adulteration by addition of water.

Total protein is one of the main quality criteria applied to goat's milk payment in many countries (Pirisi et al., 2007). Regarding protein content it was found that protein content of the examined goat's milk samples was varied from 2.71 to $4.9 \%$ with a mean value of $3.45 \pm 0.53 \%$ (Table 1). The achieved results are nearly similar to those previously obtained by Mahran (2000); Psathas (2005) and Pirisi et al. (2007). Higher estimates were recorded by Albenzio et al. (2006) and Park et al. (2007), they reported that the average protein content in goat milk was 4 and $4.6 \%$, respectively.

The variations in the results of protein content of goat's milk obtained in this study and those recorded by the other investigators could be attributed to the fact that, the individuality of the goat, breed of the animal, as well as, protein content of the feed given to the animal may affect the protein content of such milk. Moreover, the main non-individual factors of protein content variation are the stage of lactation, season, age and feeding of dairy animal.

For goat's milk, variation of total protein content depends on genetic polymorphism of á s1 casein. Generally, goat's milk contains less $\alpha$ sl casein than other ruminants' milk. Depending on the allele frequency existing for $\alpha$ s 1 casein in each breed, total protein may depend indirectly on the breed (Grosclaude and Martin, 1997). 
In addition to goat milk micelles are highly mineralized and the size of caprine micelle is significantly higher than bovine or ovine milk (Pellegrini et al., 1994). This is indirect relation to their specific technological behaviour, but the nutritional impact of these characteristics is not known.

Lactose is a valuable nutrient, because it favors intestinal absorption of calcium, magnesium and phosphorus, and the utilization of Vitamin D (Campbell and Marshall, 1975). Lactose is the main carbohydrate in milk, about $4.4 \%$ in goat's milk. Its concentration does not vary excessively (Lopez et al., 1999), however, goat's milk lactose content is often largely increased by dietary plant oil supplementation in contrast to cow milk (Chilliard et al., 2005).

It is evident from the results recorded in Table 1 that lactose percentage of goat's milk samples were ranged from 2.73 to $4.59 \%$ with a mean value of $3.99 \pm 0.32 \%$. These results are in close agreement with those obtained by Zeng and Escobar (1996) and Mahran (2000). Higher estimate of $4.7 \%$ was recorded by Albenzio et al. (2006).

According to the results presented in Table 2, it is obvious that the titratable acidity of goat's milk samples were ranged from 0.09 to $0.26 \%$ with a mean value of $0.15 \pm 0.01 \%$. These results are in close agreement with those obtained by Mahran (2000) and Park et al. (2007).

The presence of more than $0.10 \%$ titratable acidity may indicate the starting of souring and could be explained by a high load of microbial flora (several millions of bacteria per milliliter). This may reflect the hygienic status of milk obtained from such sources, and that milk may contain high numbers of bacteria that impairs its utility for heat treatment and processing.

It is worth-while to state that there were some variations in chemical composition of goat's milk obtained in this study and those recorded by other investigators. These variations could be attributed to the effect of season energy intake, presentation of the diet, amount of roughages and concentrates in the ration (feeding), the age of animals, as well as, the methods used for determination of these constituents (Brezina et al., 1993).

Additionally, there are no official and global regulations on fat and protein contents of milk other than minimum level requirements, and every regional industry has its own specifications according to market conditions and needs.

Because each of the aforementioned tests has its limitation and measure, only one or more facts of the total quality picture, a combination 
of more than one method is better than any single one for the detection of an unsatisfactory sample.

Study or investigation reports regarding counts of bacteria in goat's milk were very limited as compared to cow's milk, and mostly concerned about proportion or prevalence of these bacteria. There was also no study or investigation reports found in Qena governorate regarding counts and prevalence of indicator bacteria in raw goat's milk.

Total aerobic colony counts are used to estimate viable bacterial populations in milk and reflect the hygienic practices used in the production and handling of the milk. The performed study showed that the aerobic plate count was detected in all examined goat's milk samples and the count ranged from $2.2 \times 10^{3}$ to $8.7 \times 10^{8}$ with an average of $1.3 \times 10^{6}$ bacteria/ $\mathrm{ml}$ (Table 3 and Fig. 1). Higher result was recorded by Mahran (2000), whereas lower values were obtained by Kyozaire et al. (2005) and Taufik et al. (2008).

As shown in Table 3 and Fig. 1, coliforms organisms were found in $70 \%$ of the examined goat's milk samples with counts ranged from $1.3 \mathrm{x}$ $10^{2}$ to $5.7 \times 10^{6}$ with an average value of $3.8 \times 10^{5}$ cells/ ml. This study result of coliform counts was comparable to lower finding reported by Taufik et al. (2008), who did a pilot study to determine microbiological quality of raw goat's milk. They found that the median value of coliforms from overall goat's milk samples examined was $0.7 \times 10^{3}$.

Regarding fecal coliforms, it was detected in $40 \%$ of the total goat milk samples examined with counts varied from $<10$ to $6.2 \times 10^{2}$ with an average value of $1.7 \times 10^{2}$ cells/ $\mathrm{ml}$ (Table 3 and Fig. 1). Higher percentage of $82 \%$ was recorded by Sabreen and Abdel-Haleem (2000), they detected fecal coliforms in variable numbers in the examined goat milk samples. The presence of high numbers of coliforms\& fecal coliforms in milk provides an index of hygienic standard used in the production of milk, as unclean udder and teats can contribute to the presence of coliforms from a variety of sources such as manure, soil, feed, personnel and even water.

Concerning Enterococci, it was isolated from $46 \%$ of the examined samples and the counts ranged from $1.0 \times 10^{2}$ to $3.1 \times 10^{4}$ with an average of $1.6 \times 10^{3} \mathrm{cfu} / \mathrm{ml}$ (Table 3 and Fig. 1). Lower results were recorded by Abdel - Aal and Awad (2008). Higher enterococci counts were reported by Sabreen and Abdel-Haleem (2000) and Faschino et al. (2002). The presence of Enterococci in milk even in few numbers is considered as an index of fecal contamination. Enterococci are comparatively heat resistant, salt tolerant, can grow at a wide range of temperature and could induce certain undesirable changes in milk. Furthermore, their presence in large 
numbers could be implicated with out-break of food borne gastroenteritis (ICMSF, 1980).

The rates of $S$. aureus were very variable from $1.7 \times 10^{2}$ to $6.5 \times 10^{3}$ with an average count of $1.8 \times 10^{3}$ bacteria $/ \mathrm{ml}$ with an incidence of $36 \%$ (Table 3 and Fig. 1). This higher contamination was probably originated from goat's udder. Higher value was detected by Taufik et al. (2008), who conducted an experiment in Indonesia and stated that the median values of overall goat's milk samples examined for $S$. aureus count was $3.66 \times 10^{3}$ cells / $\mathrm{ml}$. The contamination of the milk by $S$. aureus is often original, but can also occur after handling draft in non-hygienic conditions. S. aureus is a poor competitor and is readily outgrown by lactic acid-producing microorganisms, so its growth is limited in raw milk (Holsinger et al., 1997).

Yeasts are not commonly the cause of defect in dairy products unless they ferment lactose. In this case, they can grow rapidly and produce a characteristic yeasty or fruity flavor and obvious gas (Davis and Wilbey, 1990). They also produce metabolites, e.g. short-chain fatty acids and other compounds, with known toxic effects against undesired micro-organisms in the intestinal tract (Jacobsen and Narvhus, 1996).

As shown in Table 3 and Fig. 1, yeasts and moulds were not found in four samples analyzed. The majority of positive samples had counts ranged from $1.0 \times 10$ to $2.3 \times 10^{4}$ with an average value of $1.9 \times 10^{3}$ organisms/ $\mathrm{ml}$. The result of this investigation is in agreement with the finding of Mahran (2000). This was expected as most contamination is usually bacterial in this kind of environment where hand milking is used.

\section{Conclusion}

The results of chemical analysis of this study proved that there were both types of adulteration, partial skimming and addition of water in the examined goat milk samples. The starting of samples souring could be explained by a high load of microbial flora that reflects the bad hygienic status of such milk samples. Concerning the heat treatment, it is clear that all examined goat milk samples were in raw state.

The microbiological quality was only marginally acceptable with respect to the total bacteria count. Nevertheless, the presence of pathogenic and indicator organisms, such as, coliforms, fecal coliforms, enterococci, $S$. aureus and yeasts \& molds indicate the growth of these organisms may lead to a hazard against public health. Therefore, practice and regulations, such as on-site pasteurization and implementation of HACCP following established standards, should be introduced to facilitate the production of goat milk of high quality and safety. 


\section{REFERENCES}

A.O.A.C. (1990): Association of Official Analytical Chemists. Official methods of analysis. $15^{\text {th }}$ Ed., Benjamin Franklin Station, Washington.

A.O.A.C. (2000): Association of Official Analytical Chemists. Official methods of analysis. $17^{\text {th }}$ Ed., European University Association (EUA), AOAC International, Gaithersburg, Maryland.

A.P.H.A. (1985): Standard Methods for the Examination of Dairy Products. $15^{\text {th }}$ Ed., American Public Health Association, Washington, DC.

Abdel-Aal, S.F. and Awad, E.I. (2008): Bacteriological quality of raw ewe's and goat's milk, with special references to foodborne pathogens Beni Suef. Vet. Med. J. 18, (2): 28-33.

Abou-Dawood, A.E.; Ghita, I.I. and Taha, S.M. (1980): Major and minor components and trace elements of the Egyptian ewe's and goat's milk. Egyptian J. Dairy Sci., (8): 109-115.

Albenzio, M.; Caroprese, M.; Marino, R.; Muscio, A.; Santillo, A. and Sevi, A. (2006): Characteristics of Garganica goat milk and Cacioricotta cheese. Small Rumin. Res. (64): 35-44.

Bach, A.C.; Ingenbleek, Y. and Frey, A. (1996): The usefulness of dietary medium chain trigycerides in body weight control: Fact or fancy? J. Lipid Res. (37): 708-726.

Bendixen, H.; Flint, A.; Raben, A.; Hoy, C.E.; Mu, H.; Xu, X.; Bartels, E.M. and Astrup, A. (2002): Effect of 3 modified fats and a conventional fat on appetite, energy intake, energy expenditure, and substrate oxidation in healthy men. Ame $\mathrm{J}$ of Clin Nutrition, (75): 47-56.

Brezina, P.; Prusova, M.; Pavlikova, S.; Marounek, M. and Stetina, J. (1993): The chemical composition and casein fractions of goat's milk. Potravinarske-vedy, (11): 6: 471-478.

Campbell, J.R. and Marshall, R.T. (1975): The Science of Providing Milk for Man. McGraw-Hill Book Co., New York, NY, p.: 801.

Chilliard, Y.; Rouel, J.; Ferlay, A.; Bernard, L.; Gaborit, P.; RaynalLjutovac, K. and Lauret, A. (2005): Effects of type of forage and lipid supplementation on goat milk fatty acids and sensorial properties of cheeses. In: International Dairy Federation (Ed.), Special Issue 0501, "The Future of the Sheep and Goat Dairy Sectors". International Dairy Federation, pp.: 297-311.

Chilliard, Y.; Rouel, J.; Ferlay, A.; Bernard, L.; Gaborit, P.; RaynalLjutovac, K.; Lauret, A. and Leroux, C. (2006): Optimising goat's 
milk and cheese fatty acid composition. In: Williams, C., Buttriss, J. (Eds.), Improving the Fat Content of Foods. Woodhead Publishing Ltd, Cambridge, UK, (Chapter 12), pp. 281-312.

Davis, J.G. and Wilbey, R.A. (1990): Microbiology of Cream and Dairy Desserts. In: Dairy Microbiology (Ed.: Robinson, R.K.). London and New Jersey, Applied Science Publishers, pp.: 41-108.

Deibel, R.H. and Hartman, P.A. (1976): The Enterococci. In: Compendium of Methods for the Microbiological Examination of Foods. M.L. Speck (Ed.) $2^{\text {nd }}$ Ed., American Public Health Association.

Faschino, R.; Invernizzi, A.; Barucco, R. and Stradiotto, K. (2002): Microbial composition, including the incidence of pathogens, of goat milk from the Bergamo region of Italy during a lactation year. J. Dairy Res., 69 (2): 213-225.

Grosclaude, F. and Martın, P. (1997): Casein polymorphism in the goat. In: International Dairy Federation (Ed.), Milk Protein Polymorphism, Special Issue, 9702. International Dairy Federation, Brussels, Belgium, pp.: 241-253.

Gurr, M.I. (1995): Nutritional significance of lipids. In: Fox, P.F. (Ed.), Advanced Dairy Chemistry, vol. 2 Lipids. Chapman and Hall, London, pp.: 349-402.

Güler, Z. and Park, Y.W. (2009): Evaluation of chemical and color index characteristics of goat milk, its yoghurt and salted yoghurt. Tropical and Subtropical Agroecosystems, 11: 37-39.

Harrigan, W.F. and McCance, M.E. (1976): Laboratory Methods in Food \& Dairy Microbiology. Academic Press, London, New York, San Francisco.

Harrington, P.; Archer, J.; Davis, J.P.; Croft, D.R.; Varma, J.K. and EIC officers. (2002): Outbreak of Campylobacter jejuni infections associated with drinking unpasteurized milk procured through a cow-leasing program-Wisconsin, 2001. Morbidity and Mortality Weekly Report (MMWR) (51): 548-549.

Harvey, W.C. and Hill, H. (1967): Milk Production and Control. $4^{\text {th }}$ Ed., Klewis and Co. London.

Holsinger, V.H.; Rajkowski, K.T. and Stabel, J.R. (1997): Milk pasteurization and safety: A brief history and update. Rev. Sci. Tech. Off. Int. Epiz., 16: 441-451.

International Committe Microbiological Specification for Foods (ICMSF) (1980): Microorganisms in Food. Their significance methods of enumeration. $2^{\frac{\text { nd }}{}}$ Ed. Univ. of Toronto Press, Toronto Buffalo, London. 
Jacobsen, N. and Narvhus, J. (1996): Yeasts and their possible beneficial and negative effects on the quality of dairy products. International Dairy Journal, 6: 755-768.

Kyozaire, J.K.; Veary, C.M.; Petzer, I.M. and Donkin, E.F. (2005): Microbiological quality of goat's milk obtained under different production systems. J. Sci. African Vet. Assoc., 76 (2): 69-73.

Lampert, L.M. (1975): Modern Dairy Products. $3^{\text {rd }}$ Ed., Chemical Pub. Co., Inc., New York.

Lopez, M.B.; Luna, A.; Laencina, J. and Falagan, A. (1999): Cheesemaking capacity of goat's milk during lactation: Influence of stage and number of lactations. J. Sci. Food Agric., (79): $1105-1111$.

Mahran, M.A. (2000): Sanitary condition of goat's milk in Upper Egypt. M.V.Sc. Thesis, Fac. Vet. Med., Assiut Univ., Egypt.

Mercuri, A.J. and Cox, N.A. (1979): Coliform and Enterobacteriaceae isolates from selected foods. J. Food Prot., 42 (9): 712.

Muehlherr, J.E.; Zweifel, C.; Corti, S.; Blanco, J.E. and Stephan, R. (2003): Microbiological quality of raw goat's and ewe's bulktank milk in Switzerland. J. Dairy Sci. (86):3849-3856.

Mumm, H. (1970): Handbuch der Landwirtschaftlichen. Versuchs - und untersuchungsmethodik (Methodenbuch). Dritte Auflage, Seite: 44 (Cited after Sabreen, 1992).

Paccard, P. and Lagriffoul, G. (2006a): Synthèse bibliographique sur la composition des fromages de brebis en composés d'intérêt nutritionnel. Personal Communication, pp.: 24. (Cited after Raynal-Ljutovac et al., 2008).

Paccard, P. and Lagriffoul, G. (2006b): Synthèse bibliographique sur la composition du lait de brebis en composés d'intérêt nutritionnel. Personal communication, pp 28. (Cited after Raynal-Ljutovac et al., 2008).

Park, Y.W. (1994): Hypo-allergenic and therapeutic significance of goat milk. Small Rumin. Res., (14): 151-161.

Park, Y.W.; Ju'arez, M.; Ramosc, M. and Haenlein, G.F. (2007): Physicochemical characteristics of goat and sheep milk. Small Rumin. Res., (68): 88-113.

Pellegrini, O.; Remeuf, F. and Rivemale, M. (1994): Evolution of physicochemical characteristics and renneting properties of ewe's milk collected in "Roquefort area". Lait., 74: 425-442.

Pirisi, A.; Lauret, A. and Dubeuf, J.P. (2007): Basic and incentive payments for goat and sheep milk in relation to quality. Small Rumin. Res., (68):167-178. 
Psathas, G. (2005): Halloumi Cheese-Case Study of Cyprus. International Dairy Federation, 0501, part (2): 90-97.

Raynal-Ljutovac, K.; Lagriffoul, G.; Paccard, P.; Guillet, I. and Chilliard, $Y$. (2008): Composition of goat and sheep milk products: An update. Small Rumin. Res., (79): 57-72.

Razafindrakoto, O.; Ravelomanana, N.; Rasolofo, A.; Rakotoarimanana, R.D.; Gourgue, P.; Coquin, P.; Briend, A. and Desjeux, J.F. (1993): Le lait de chèvre peut il remplacer le lait de vache chez l'enfant malnutri? Lait., 73 (5-6): 601-611. (Cited after Haenlein, 2004)

Sabreen, M.S. (1992): A subscription for strategic control of mastitis, its public health hazards and judgement in friesian dairy cattle. Ph.D. Thesis, Fac. Vet. Med., Assiut Univ., Egypt.

Sabreen, M.S. and Abdel-Haleem, Amal, A. (2000): Microbiological evaluation of sheep's and goat's milk in Assiut Governorate. Assiut Vet. Med. J., 42 (84): 36-46.

Schulz, Z.M.; Voss, E.; Myowetz, G.; Leder, K.H. and Warnecke, E. (1953): Adaption of formal titration to the requirement of dairy control. Kieler Milchwirtscaftlich Forschungsherichte, (5): 273-295 (Cited after Sabreen, 1992).

St Onge, M.P. and Jones, J.H. (2002): Physiological effects of medium chain triglycerides: Potential agents in prevention of obesity. $\mathrm{J}$. Nutr. (32): 329-332.

Taufik, E.; Wirjantoro, T.I.; Kreausukon, K. and Hildebrandt, G. (2008): Microbiological investigation of raw goat milk from commercial dairy goat farms in Bogor, Indonesia Proceedings, the $15^{\text {th }}$ Congress of FAVA. 27-30 October, FAVA-OIE Joint Symposium on Emerging Diseases.

Telliez, F.; Bach, V.; Leke, A.; Chardon, K. and Libert, J.P. (2002): Feeding behavior in neonates whose diet contained medium-chain triacylglycerols: Short-term effects on thermoregulation and sleep. Am. J. Clin. Nutr., (76): 1091-1095.

Zeng, S.S. and Escobar, E.N. (1996): Factors affecting somatic cell count of goat milk throughout lactation: Parity and milk production. In: Rubino, R. (Ed.), Proceedings of the International Symposium on somatic cells and milk of small ruminants. EAAP Publication No. 77, Wageningen Pers, Bella, Italy, September 25-27, 1994, pp. 157-160. 